\title{
Mafia Children: From Future to Past. Knowing Other Realities to Learn Freedom
}

\author{
ROSELLA MARZULLO \\ University of Rome Tor Vergata, Italy
}

\begin{abstract}
In mafia families, children are educated in violence, revenge, and gender stereotypes. What can be done to guarantee these children the right to education, the right to become citizens, the right to be men without killing and women without obeying, and the right to know the value of democracy and legality? One possible answer lies in the recent judgment of the Juvenile Court of Reggio Calabria, which has mandated the revocation of parental responsibility in all cases in which serious injury to the child is proven. These limitations to parental rights have the principal purpose of allowing institutions to stop a system of behaviour that is harmful to the proper development of the personality of the child and that transmits negative cultural values from father to son and from mother to daughter.
\end{abstract}

\section{Keywords}

mafia, education, gender, blood ties, law

\section{Introduction}

Assuming that the objective of education is the emancipation of the subject in formation, this research addresses the problem of compatibility between the educational models popular among families belonging to the mafia and educational models seeking to create free, emancipated, and autonomous persons. Bauman (1999) argues that centre of the current crisis of the political process is not so much the absence of values or the confusion generated by their plurality as it is the absence of an institution powerful enough to produce legitimate representatives, to promote and strengthen any set of values, or to implement any range of consistent and cohesive options.

Man acquires morality from the environment in which he grows, but the true evolution of morality can be accomplished only through the critical skills learned during the complex phenomenon of training. In other words, only if one learns to be critical can one participate in the common good. Spadafora (2010) illustrated this point as follows: 'Democracy, before being political technique to modify and adapt to social and economic changes, it is basically a way of life that only a critical pedagogy can favour.' However, if families educate their children using values opposite those of democracy, legality, solidarity and the common good, how do you guarantee children the right to education and the right to become informed citizens who are integrated into their social context? 
During my research on this subject, I examined the recent judgments of the Juvenile Court of Reggio Calabria, Southern Italy, where a judge is pioneering a programme to help children of mafia families escape from a life of crime by taking them away from their parents at the first sign of trouble. The objective of these judges is to allow children who are growing up in similar contexts to learn about other realities in order to undermine the educational models inherited from their families of origin.

By applying the educational theories of Piero Bertolini (1965) and Jack Mezirow $(1991,1995)$, I believe it is possible to deconstruct deviating training models through experience. Training models should be aimed at the rehabilitation of persons who, for whatever reason, have introjected internal dysfunctional models and are incapable of developing appropriate relationships with others or society in general; such models need to begin with the epistemological foundation of the rehabilitation pedagogy. This is the case of the work of two great academics of the phenomenon of experiential learning who have worked to implement this transformative movement: Bertolini (1965) in Italy and Mezirow $(1991,1995)$ in the United States. Both researchers have claimed that every experience that crosses a human being's path causes more or less significant change.

For this reason, it is very important to begin with the epistemological foundation of the rehabilitation pedagogy to build the most appropriate educational interventions for children removed from the 'Ndrangheta families by order of the juvenile courts. Such a foundation can only be traced through the intersection of the perspectives of Bertolini (1965) and Mezirow (1991, 1995). Experience underlies learning, and it is capable of inducing deconstructions and new constructions of the self and encouraging the processes of transformation that facilitate the departure of children belonging to mafia families from their contexts of origin.

\section{Context and Research Question}

In mafia families, children are educated in the violence, revenge, and gender stereotypes that underpin the real strength of the clans, which are organised by families to control entire territories through intimidation and oppression. Clans are based on blood ties and on strongly hierarchical and patriarchal family models: Men have the power to make any decision concerning their wives and children, and women have the task of handing down this familiar pattern. The bond of blood is the real core of the mafia, since clans close themselves within their household, leaving out the outside world and its rules.

The strength of blood ties makes it particularly hard for security forces to penetrate clans. While the Sicilian mafia has been undermined by the so- 
called 'Pentiti', who have collaborated with the police and informed on their fellow criminals, the 'Ndrangheta has not. In the case of the 'Ndrangheta, no one helps the police because the mafia is structured on the strength of ties among families, who transmit their codes from one generation to the next.

However, children who grow up in such contexts are entitled, like all children, to be educated about the principles of legality, solidarity, human dignity, and alternative stand points. Italian regulations, including Civil Code Art. 315 bis and the international conventions to protect children (including the International Convention on the Rights of the Child, which was signed in New York on November 20,1989) recognise children's right to education.

Thus, the research question of this study is: How can we ensure the right to education of mafia children? One possible answer could be the path chosen by the judges of the Juvenile Court of Reggio Calabria, who mandated that, in cases that could be considered parental abuse of children among mafia families, the children can be taken away.

The methodological approach used to pursue this question is the case study and review of recent judgments of the Juvenile Court of Reggio Calabria, Southern Italy, where Judge Roberto Di Bella is pioneering a programme to help children who belong to mafia families escape a life of crime by taking them away from their parents at the first sign of trouble. To develop a comprehensive answer, I examined these judgments and the relevant psychological (Bruner 1986), pedagogical (Bertolini 1965), and sociological (Bandura 2000) literature.

Judge Di Bella's approach stems from the need to find a way to break the mafia cycle, which transmits negative cultural values from father to son. The region of focus, Reggio Calabria, is the heartland of one of the country's most terrible mafia groups: a criminal network known as the 'Ndrangheta, which is also the largest cocaine smuggling group in Europe. The sentences arise from an analysis of statistical data conducted by the judges of the Juvenile Court of Reggio Calabria, which, in the last twenty years, has treated over one hundred prosecutions of mafia-associated crimes and more than fifty cases of murders and attempted murders committed by children, many of whom were subjected to harsh prison terms, were killed during family feuds, or have assumed leadership of the 'Ndrangheta.

The judgments are novel for two reasons. First, they are the first to use pedagogical criteria in developing judicial decisions aimed at showing mafia children a world different from the one in which they grew up. Second, they draw parallels between classic assumptions of child abuse (e.g. beatings, psychological and physical violence) and cases in which children are exposed to violence, expected to follow the strict rules of the family, educated in 
killing and revenge (if they are males), or taught to perform the duties of wives and mothers (if they are females).

Education is seen as the only possibility of deconstructing these children's deviant educational models, and the law may be the only way to support this principle and the value of the educational function. This is particularly true if we reflect on the danger of the transmission of negative cultural values from one generation to another, following gender stereotypes useful to the consolidation of a criminal force.

The family's critical role in consolidating the strength of the 'Ndrangheta is demonstrated by the group's practice of arranging marriages among individuals from different clans in order to strengthen relations among mafia families. Marriages, in fact, have a high symbolic value and are infused with the idea of the family as a nucleus impenetrable from the outside. For this reason, marriages have been repeatedly used to sanction the end of a feud. The 'Ndrangheta began as a structured organisation of families, each of which had full power and control over the territory in which it operated. These families confidently managed both licit and illicit monopoly activities.

In my research, I highlighted the danger that exists for children who grow up in 'Ndrangheta families, which stems from the unwritten codes through which these families transmit negative values to their children. Because of these codes and values, the sons of mafia bosses, particularly the first-born sons, are predestined to follow in their fathers' footsteps. Similarly, daughters are sometimes compelled to marry the sons of other bosses, thus binding separate clans together through blood relations.

Because of this differentiation of tasks within the criminal organisation, women have always been engaged in traditional tasks and relegated to the private sphere. Tasks perceived to be vital and essential within the female universe can be distinguished as either active or passive. Active tasks involve transmitting the cultural mafia code to children and encouraging them to engage in vengeance. It is a mother's duty to inculcate in her children silence, gender differences, and contempt for public authorities, while simultaneously playing the role of a custodian of honour, keeping the flame of vengeance for offended men alive. Within the 'Ndrangheta, one can speak of a real 'pedagogy of revenge,' which involves continuously inciting children to avenge the honour of fathers and brothers killed by the mafia.

These passive features give women two fundamental tasks. First, they must, through their own respectability and integrity, protect the authority of the masculine reputation of the men formally affiliated with the mafia. Second, they must be considered objects within arranged marriages, through which they serve the strategic purpose of broadening or ending alliances, sometimes 
after years of feuding between clans. In other words, women are slave to both male and family will.

This role of women within the 'Ndrangheta is ambiguous and contradictory, and modern female members participate in both traditional and criminal tasks. For example, as the criminal organisation enters the drug trafficking market, a new generation of women, who are younger and more educated, is adapting to the mafia system and beginning to take active part in drug trafficking. Within this function, women are enlisted as couriers and drug dealers, since the transportation of drugs is a task that is particularly suitable to women, who can easily hide quantities of drugs by simulating pregnancy or rounded hips and breasts. Modern mafia women are also directly involved in managing mafia power and holding command positions in the organisational structure, especially when the male figure is absent (e.g. due to being in prison or being an absconder). In these situations, women deliver written or oral messages on behalf of clan members and are temporarily delegated to manage male power.

However, this does not mean that women have a real path of empowerment within the mafia, since these roles are always temporary and involve only pseudo-emancipation. Instead, due to the patriarchal system, women continue to suffer physical and psychological violence and to be economically dependent on men.

For these reasons, today's mafia women are rejecting the role of the guardians of the pedagogy of revenge. They no longer want their sons to be killed in family feuds or their daughters forced to marry bosses' sons, they are challenging the vengeful pursuits of their husbands and other family members, and they are turning to judges in juvenile courts to save their children.

\section{Methodology}

The methodology used in this research was a case or document analysis, conducted using the judgements of the Juvenile Court of Reggio Calabria. From a scientific point of view, these judgments can be framed as documents. A document analysis is a valid method of investigation in empirical research, especially when it is integrated with other methods (Gibson and Brown 2009: 65). However, since there is no consensus on what can be considered a document (Flick 2014: 377), it is important to specify. Here, a document refers to:

Information material on a particular social phenomenon that exists independently of the researcher. It therefore is produced by individuals or institutions for purposes other than those of social research: this however you can use it to take possession of their knowledge purposes. (Corbetta 1999: 437) 
One of the main benefits of document analysis is that it avoids potential problems related to the relational dimensions of other research methods (e.g., in cases of interviewers and interviewees: the interviewee looking for approval, the interviewer exerting influence, etc.). At the same time, however, in a document analysis, the researcher is unable to explore beyond what is written (Corbetta 1999). For this reason, it may be useful to combine document analysis with other types of investigation.

I chose to examine the Italian legislation on the right to education, as expressly expressed in Article 315 bis of the Civil Code, and the international law recognising the same right (i.e., the International Convention on the Rights of the Child, which was signed in New York on November 20, 1989). The studied judgments pertain to the principles of the right to education in both Italian and international law.

I also chose to cross-examine the given documents (i.e., the judgments), which show the dysfunction of family relationships in mafia families, with the historical foundations of so-called amoral familism. The origins of the familistic culture reside in the history of Southern Italy in general and, in particular, in the history of Calabria. The latter was a land of conquest dominated by foreign powers. In Calabria, this conquest by foreign powers produced different reactions; however, too often, conquered populations shared an atavistic resignation, which is an unconditional surrender to the ruler in power. As a result of this history of conquest by foreign powers, the Calabrian region lacks the prerequisites for the construction of a culture of the State, especially as expressed through an ethos of shared values and justice for all. One symptom of this situation is the fact that a significant proportion of Calabrian families pay 'protection money' to the 'Ndrangheta, but do not pay taxes to the State.

Why does this happen? The history of domination and the consequential root of a mentality of mistrust towards the state, which is perceived as alien and oppressive, has encouraged the spread of a culture of custody and protection via the mafia in order to ensure the survival of individuals, their families, and their businesses. This school of thought, labeled 'amoral familism' by Banfield (1958), has produced a backward society in southern Italy. It has also led to an extremist conception of family ties that adversely affects individuals' ability to associate beyond the boundaries of the family and, thus, the collective interest.

Individuals typically base their actions on maximising the short-term material advantages of their nuclear families, and they assume that all others will behave the same way. This explains why the codes that mark the life of the clan are not only symptoms of strength, but also expressions of the mafia culture and of the ways of thinking and acting in the context of the clan. 


\section{New course introduced by the judges of Reggio Calabria: Proposals for action on mafia children following removals. Re-education projects}

The jointly gathered and stored data show that growing up in mafia families continually exposes children to the logics of domination and subjection, with implications for both emancipation and cognitive and emotional development. Here, pedagogy and rights merge into a single objective: the protection of children. This may extend to the decision to revoke parental responsibility in all cases in which the existence of a serious injury to the child, whose needs, desires, inclinations, and feelings are crushed by an adult world incapable caring for him or her, is established.

Italian law gives parents the opportunity and authority to fulfil their duties and fully carry out their responsibilities for their children. Parental power and authority are not to be used for their own personal interest or the interests of the family or clan; instead, they should be used to develop the family's children. Parental authority is, therefore, power for the child, not power over the child. Indeed, such power does not create subjective rights for the parents, but gives them an officium or a munus-in which the power is not discretionary but instrumental - to be used for the purposes for which the power is given, which is to support an appropriate course of education for the child.

What happens, then, if the exercise of power results in injury to the child? What should the law do if the conduct of the parent denies the true meaning of the officium conferred by the law and natural law? Several pre-judgement measures have been designed to ensure the interests of the child in the event of danger; these involve the work of social services and the judiciary. The intervention of the Court in the education process is very marginal in terms of the physiology of the relationship between parents and their children. Furthermore, with regard to the particular assumptions of the differences among spouses regarding pedagogical choices, the law limits Court appeals to only the most serious cases.

The intervention of the Court, in fact, is an instrument of protection marked by the principle of minimal invasiveness in the sphere of autonomy which is the family, so much so that the Court is prevented from engaging, except in cases of 'issues of particular importance.' The law is not expected to provide the magistrate with power replacing that of a child's parents; instead, it confers only the power to mediate the power of the parents. That said, it is natural that, in cases of intra-family pathologies, violence, abuse, and any kind of injury to a child's mental or physical development, the intervention of the Court is not only relevant, but necessary. The State cannot fail to guard the rights of individuals, such as children, who do not have adequate means to protect themselves independently. 
Thus, the limitation of parental rights has this principal purpose: to allow institutions to stop, even temporarily, a system of behaviour prejudicial to the proper development of the personality of the child or continuous aggression by adults who cause (even unintentionally) irreparable damage to the child's development.

In this context, the judgments on the children of the mafia are very important because they make it possible to intervene at the beginning of a child's acquisition of the 'Mafiosi' mentality. When these children are accused of bullying or vandalism, and their families do nothing, the Juvenile Court intervenes by taking the children away from their relatives and placing them in social services. Social services are indispensable to this decision because they provide necessary assistance, support, and supervision, integrating children into community structures outside of Calabria that are suitable to their needs. These community structures must include operators who are professionally qualified to treat the problems facing mafia children and provide real alternatives to the cultures from which these children come. In this context, social services manage the entire phase of the placement of a child outside his or her family of origin (i.e., away from Calabria) and coordinate rehabilitation projects with family home educators or foster families.

Such rehabilitation projects are essential for demonstrating the power of education. The objective of the Court, indeed, is to show these young children a world different from that in which they grew up. Thus, time must reverse its course: from future to past. Only cultural contamination and an awareness of other worlds and different ways of life can give mafia children a different future, away from crime. If the centre of a child's culture is his or her family of origin and its rules, then children may never learn other ways of thinking or acting that oppose the rules and roles of their families of origin. Here, the complex relationship between law and education becomes evident: The law educates children who would otherwise simply join the law of blood, offering them new possibilities for the future.

\section{Conclusions}

In this interpretation, key rights to education, information, and the possession of a minimum income become pre-requisites of the democratic process and, thus, of citizenship. The international legal recognition of children's rights makes these rights fundamental and, as such, guaranteed.

One very significant example of this international legal recognition is Art. 28 of the 1989 International Convention on the Rights of Children (which essentially incorporates Art. 26 of the Universal Declaration of Human Rights). This rule mandates state parties to recognise the rights of children to 
education and, in particular, to recognise the duty of the State to ensure the progressive exercise of this right on the basis of equal opportunity. Among other things, these rules require all states to take all measures necessary to guarantee these rights, including by offering financial assistance in cases of need. Because citizenship education is an integral part of human rights education and the core of any goals related to education and training aimed at building a universal and democratic culture, it must be guaranteed to those who are deprived.

This is the only way to give mafia children a different future and a chance in society: education in the culture of democracy and information and the dissemination of the principles according to which every person has the power and duty to achieve self-realisation and contribute to the functioning of the system-state. This objective can be achieved by applying the transformative learning theory during the process of rehabilitating children who have been removed from mafia families.

From this perspective, educators must assume responsibility for setting objectives that explicitly include autonomous thinking and must recognise that accomplishing these objectives requires designing experiences to foster critical reflectivity and experience in discourse. Education that fosters critically reflective thought, imaginative problem posing, and discourse is learner-centred, participatory, and interactive, and it involves group deliberation and group problem solving. Instructional materials should reflect the real-life experiences of the learners and be designed to foster participation in small-group discussions to assess reasons, examine evidence, and arrive at reflective judgments. Learning takes place through the discovery and imaginative use of metaphors to solve and redefine problems.

To promote learning discovery, an educator often reframes learners' questions in terms of the learners' current levels of understanding. Learning contracts, group projects, role plays, case studies, and simulations are classroom methods associated with transformative education. The key idea of such education is to help learners actively engage in concepts presented in the contexts of their own lives and to collectively and critically assess the justification of new knowledge.

Together, learners undertake action research projects. They are frequently challenged to identify and examine assumptions, including their own. Methods that have been found useful in accomplishing these objectives include critical incidents, metaphor analyses, concept mapping, consciousness raising, life histories, repertory grids, and participation in social action (Mezirow and Associates 1990). 
This route can facilitate the achievement of a new culture of legality. However, it is necessary to educate and re-educate children through experiences and comparisons with worlds that are different from those learned during early ages, when they have no alternatives. This is why the removal of mafia children from their families results in pedagogical activity; more than anything else, this approach facilitates the teachings of Platonic Socrates: that the law teaches and improves the youth generation.

\section{References}

Abbagnano, Nicola (1993) Storia della Filosofia. Vol. 1, Torino: Utet.

Ainsworth, M., and Bowlby, J. (1965) Child Care and the Growth of Love. London: Penguin Books.

Alvaro, Corrado (2000) Gente in Aspromonte. Milano: Garzanti Libri.

Arendt, Hannah (1990) Teoria del Giudizio Politico. Lezioni Sulla Filosofia Politica di Kant, Genova: Il Melangolo.

Arendt, Hannah (2001) La crisi dell'istruzione. In: Tra Passato e Futuro. Milano: Bompiani.

Ariès, Philippe (1999) Padri e figli nell'europa medievale e moderna. Roma-Bari: Laterza.

Arlacchi, Pino (2007) La mafia imprenditrice. Dalla Calabria al Centro dell'inferno. Milano: Il Saggiatore.

Bandura, Albert (2000) Autoefficacia: Teoria e Applicazioni. Trento: Edizioni Erikson.

Banfield, Edward (1976) Le Basi Morali di una Società Arretrata. Bologna: il Mulino.

Barone, Pierangelo (2001) Pedagogia della Marginalità e della Devianza. Milano: Guerini.

Bauman, Zygmunt (1999) In Search of Politics, Tr. It. (2003) La Solitudine del cittadino globale. Milano: Feltrinelli.

Berlin Isaiah (1982) Two concepts of liberty. In Four Essays on Liberty. Oxford: Oxford University Press.

Bertolini, Piero (1965) Per una Pedagogia del Ragazzo Difficile. Bologna: Malipiero. 
Bianca, Cesare Massimo (1981) Diritto Civile vol. II. Milano: Giuffrè Editore.

Bowlby, John (1999) Attaccamento e Perdita, vol. 1. Torino: Bollati Boringhieri.

Brentano, Franz (1997) La Psicologia dal Punto di Vista Empirico. Roma: Laterza.

Bretherton, I., and Munholland, K. (1999) Internal working models in attachment: A construct revisited. In Cassidy, J. and Shaver, P. (eds.) Handbook of Attachment: Theory, Research and Clinical Application. New York: Guilford Press.

Brofenbrenner, Urie (2010) Rendere Umani Gli Esseri Umani, Bioecologia dello Sviluppo. Trento: Centro Edizioni Erikson.

Bruner, Jerome Seymour (1986) Actual Minds, Possible Worlds. Cambridge: Harvard University Press.

Ciconte, Enzo (1992) Ndrangheta dall'unità a Oggi. Bari: Laterza.

Ciconte, Enzo (2008) Ndrangheta. Cosenza: Rubbettino Editore.

Corbetta, Piergiorgio (1999) Metodologia e tecniche della ricerca sociale. Bologna: Il Mulino.

Cranton, P. (1996) Professional Development as Transformative Learning: New Perspectives for Teachers of Adults. San Francisco: Jossey-Bass.

Cranton, P. (1994) Understanding and Promoting Transformative Learning: A Guide for Educators of Adults. San Francisco: Jossey-Bass.

De Leo, G. and Patrizi, P. (2007) Psicologia della Devianza. Roma: Carocci.

Delors, J. L. J. (1997) Nell'Educazione un Tesoro. Roma: Armando.

Dewey, John (1888) The Ethics of Democracy. In The Early Works, vol. I. (1969). Cambondale-Edwardswille: Southern Illinois University Press.

Dewey, John (1897) My Pedagogic Creed. In Borghi Lamberto (ed.) Il mio credo pedagogico. Antologia di Scritti sull'educazione (1954). Firenze: La Nuova Italia.

Ducci, Edda (1994) Libertà Liberata, Libertà Legge Leggi. Roma: Anicia.

Erikson, E. H. (1968) Identity Youth and Crisis. New York: Norton Company.

Flick, U. (2014) An Introduction to Qualitative Research fifth edn. London: Sage.

Forgione, Francesco (2008) 'Ndrangheta. Boss luoghi e affari della mafia più potente al mondo. Milano: Baldini Castoldi. 
Foucault, Michel (1976) Sorvegliare e punire. La nascita della prigione. Torino: Einaudi.

Foucault, Michel (1992) Storia Della Follia Nell'età Classica. Milano: Rizzoli.

Freud, Anna (2012) l'osservazione del bambino. Torino: Bollati Boringhieri.

Gibson, W. and Brown, A. (2009) Working with Qualitative Data. London: Sage.

Gonzi, A. et al. (1995) Key Competencies in On the Job Training. Sydney: University of Technology and Science and Department of Industrial Relations, Employment and Training.

Gratteri, N., Nicaso, A. and Borrelli, M. (2008) Il grande inganno. I falsi valori della 'ndrangheta. Cosenza: Pellegrini Editore.

Habermas, Jürgen (2007) La Condizione Intersoggettiva, Roma-Bari: Laterza.

Habermas, Jürgen. (1981) The Theory of Communicative Action: Reason and the Realization of Society, vol. 1. Boston: Beacon Press.

Heidegger, Martin (2009) Essere e tempo. Milano: RCS-Bompiani.

Hilmann, James (2004) l'anima dei Luoghi. Milano: Rizzoli.

Hobsbawm, Eric John (1976) Il Trionfo della Borghesia, 1848/1875. Bari: Laterza.

Hobsbawm, Eric John (2007) Il Secolo Breve: 1914-1991: l'Era dei Grandi Cataclismi. Milano: Rizzoli.

Maritain, Jacques (2009) La Persona E Il Bene Comune. Milano: Morcelliana.

Mattei, Francesco (2012) Tracce Di Paideia. Abbondanza E Privazione nell'avventura dell'educazione, Roma: Anicia.

Matza, David (1969) Becoming Deviant. Englewood Cliffs, NJ: Prentice Hall.

McAdams, D. P. and de St. Aubin (ed.) (1992) A theory of generativity and its assessment through self-report, behavioral acts, and narrative themes in autobiography. Journal of Personality and Social Psychology 6, 62, pp. 1003-1015.

Mezirow, Jack, and associates (Eds) (1990) Fostering Critical Reflection in Adulthood, San Francisco: Jossey-Bass.

Mezirow, Jack (1991) Transformative Dimensions of Adult Learning. San Francisco: Jossy-Bass. 
Mezirow, Jack (1995) Transformative Theory of Adult Learning. In Welton, M (ed.), In Defense of the Lifeworld. Albany: State University of New York Press.

Mezirow, Jack (1996) Contemporary paradigms of learning. Adult Education Quarterly 3, 46, pp. 158-172.

Paoli, Letizia (2000) Fratelli di Mafia. Cosa Nostra e Ndrangheta. Bologna: Il Mulino.

Platone, Fedone. Translated by M. Valgimigli. Roma-Bari 2000.

Platone, La Repubblica. F. Adorno (ed.). In Tutti i dialoghi. Utet, Torino, 1988.

Rousseau, Jean-Jacques (2007) Emilio o dell'educazione. Milano: Oscar Mondadori.

Scabini, E. and Iafrate, R. (2003) Psicologia dei Legami Familiari. Bologna: Il Mulino.

Simmons, Laura K. (2012) The Handbook of Transformative Learning: Theory, Research, and Practice. In Taylor, E. W., Cranton, P. and Associates (eds.). San Francisco, Ca: Jossey-Bass.

Steiner, George (2003) Le Antigoni. Milano: Garzanti.

Winnicott, Donald Woods (1968) La Famiglia e lo Sviluppo dell'individuo. Roma: Armando.

\section{Judgments}

Supreme Court (Civil law) 20.04.1990 n. 3307.

Supreme Court (Civil law) 27.05.1987 n. 4723.

Court of Appeal (Juvenile court), Milan 12.12.74.

Criminal Court, Milan 30.03.2012.

Criminal Court of Appeal, Milan, 29.05.2013.

Court of Appeal Reggio Calabria, 18.01.2013.

Civil Court Milan, 04.02.2010.

Juvenile Court Reggio Calabria, 19.07.2012.

Juvenile Court Reggio Calabria, 6.03.2012. 